\title{
水頭症の内視鏡手術に必要な解剖と知識
}

\author{
西山 健一1)，藤井 幸彦1） \\ 1）新潟大学脳研究所脳神経外科
}

\section{Surgical Anatomy for Endoscopic Surgery in Hydrocephalus}

\author{
Kenichi Nishiyama, M.D. ${ }^{1)}$, and Yukihiko Fujii, M.D. ${ }^{1)}$ \\ 1) Department of Neurosurgery, Brain Research Institute, University of Niigata
}

This article describes the surgical anatomy for various endoscopic procedures to deal with a variety of cerebrospinal fluid pathway obstructions. The procedures are roughly classified into two tasks: the creation of a bypass into the cisterns and the restoration of the obstructed cerebrospinal fluid pathway. A thorough knowledge of the structure and vasculature in the cistern is required for the success of the former and neural fiber and nucleus under the ventricle should be ascertained for the latter. Usually third ventriculostomy is performed behind the clivus, halfway between the infundibular recess and mammillary bodies in the midline. Both the interpeduncular and prepontine cisterns should be inspected through the ventriculostomy with perforation of two leaves of Liliequist's membrane. In temporal ventriculostomy, blunt perforation should be done at the tip of the inferior horn, laterally from the choroidal fissure line to avoid injuring the anterior choroidal artery. In aqueductoplasty, gentle inflation of the balloon to perforate the obstructive membrane is required in order to protect the oculomotor nucleus, medial longitudinal fasciculus and trochlear nerve fiber seated close to the ependymal layer. Finally, because anatomical variations are sometimes observed in cases with hydrocephalus, preoperative high resolution MR-images are essential prior to performing these procedures.

(Received December 25, 2012; accepted January 11, 2013)

Key words : hydrocephalus, neuroendoscope, third ventriculostomy, aqueduct, Liliequist's membrane Jpn J Neurosurg（Tokyo）22 : 349-356, 2013

\section{はじめに}

1980 年代後半, 光学系機器の進歩に伴い脳室鏡とその 周辺機器の開発が進み, 内視鏡下第三脳室底開空術 (endoscopic third ventriculostomy：ETV) がシャントと並 ぶ水頭症治療の術式として認知されるに至った。 以後, 水頭症および関連する囊胞性疾患に対し, 髄液循環路を 作成する各種脳室鏡手術が考案されている。ここで術式 は “脳室一脳槽短絡術” と “脳室内閉塞機転の解除” に 大別され, 前者では脳槽の構造と走行する血管構築の, 後者では脳室壁直下の神経路と神経核の位置を把握して
おくことが必須である。また，特に本邦で頻用される軟 性鏡操作では，その自由度の高さゆえに上下・左右の才 リエンテーションを失いやすい，そこで鏡視下の臨床解 剖を熟知して，いくつかのランドマークを覚えておくこ とが肝要となる。

本稿では, 脳室一脳槽短絡術として ETV, 側脳室下角一 脳槽短絡 (temporal ventriculostomy), 四丘体槽くも膜囊 胞 (quadrigeminal cistern arachnoid cyst) の手術, 脳室内 閉塞解除として内視鏡下中脳水道形成術 (endoscopic aqueductoplasty：EAP）で必要とされる内視鏡外科解剖 とおのおののアプローチについて解説する. 


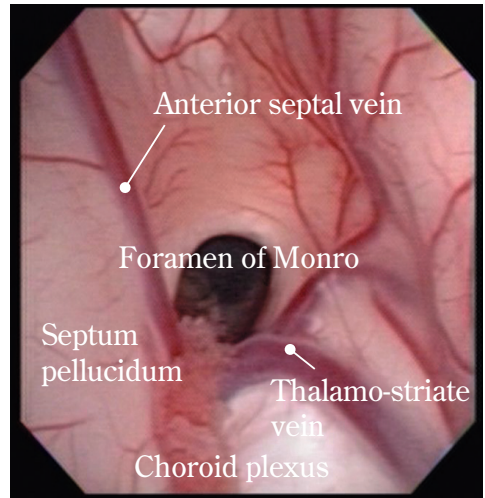

Fig. 1 An endoscopic image from the right anterior horn

\section{Third ventriculostomy}

\section{1 手技と脳室内のランドマーク}

ETV は側脳室前角から脳室鏡をアプローチする標準 術式である. 左右いずれかの前頭葉を経由して前角に至 ると, 通常まずモンロー孔, 前中隔静脈（anterior septal vein), 視床線条体静脈 (thalamostriate vein), 脈絡叢, 上脈絡丵静脈 (superior choroidal vein), 透明中隔が観察 される（Fig. 1)。モンロー孔は脈絡叢を前方にたどり前 中隔静脈, 視床線条体静脈, 上脈絡叢静脈が合流する部 位に確認できる。正常では前後径で約 $3.5 \mathrm{~mm}$ 程度の卵 円形を呈し，その前内方には脳梁が白色調を带びた弓状 の高まりとして観察される。モンロー孔の内側面を経て 脈絡叢のさらに内側には脳弓が存在し, 脈絡叢の外側に は視床が緩やかな隆起をもって認められる。モンロー孔 を経由して第三脳室に到達するとその底部に一対の乳頭 体（mammillary body），下垂体へ続く赤色を呈した漏斗 陥凹 (infundibular recess) とその前方の視神経交叉 (optic chiasm）を，さらにその前方に薄い終板（lamina termi-

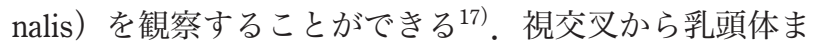
での距離は約 $6.0 \mathrm{~mm}$ 程度で, ここに ETVで穿孔すべき 灰白隆起（tuber cinereum）を認める。比較的長期に経過 した水頭症状態では，乳頭体は明確に分かれ半円状とな り, 灰白隆起は薄く透明化している，ETVでは “両側乳 頭体と漏斗陥凹とを結ぶ三角形の中心”（Fig. 2）を目印 として, 灰白隆起へ開空するのが基本である ${ }^{17) 18)}$ ，加え て第三脳室底直下の Liliequist's membrane も穿孔し, “to and fro movement”により第三脳室底の上下運動が出 現するか否かで開空の正否を術中判断できる。乳頭体の 後方は中脳被蓋（tegmentum）を形成し中脳水道までな だらかな斜面状となり，その後上方には後交連（poste-

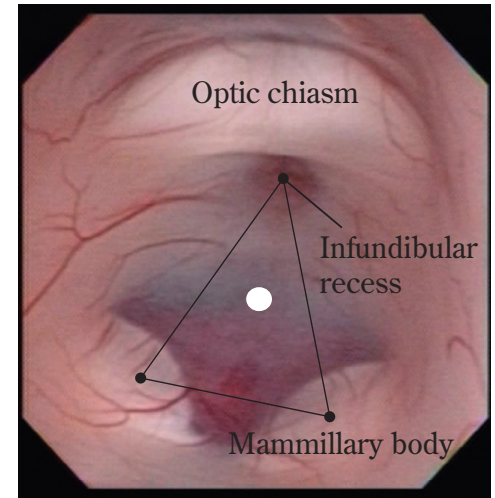

Fig. 2 An endoscopic image of the third ventricular floor

The center of the triangle formed by the infundibular recess and the bilateral mammillary bodies is the ETV landmark.

rior commissure)，松果体陥凹（pineal recess），手綱交連 (habenular commissure)さらには中間帆 (velum interpositum）まで確認できる17).

\section{2 脚間槽}

長期に経過した水頭症状態では第三脳室底が菲薄化 し，脚間槽（interpeduncular cistern）内の構造が透見可 能であるが，直下の構造がまったく見えない状況で穿孔 することも多い．脚間槽は矢状断像で捉えると，上下を 二葉の Liliequist's membrane で境されている。鞍背から 両側乳頭体に向かう diencephalic leaf と, 脳底動脈前面 に向かい脚間槽前壁および prepontine ligament を構成 していく mesencephalic leaf がそれであり，特に前者は 第三脳室底の穿孔時に同時穿破が必須な膜構造である. また両外側は diencephalic-mesencephalic leaves に囲ま 孔る2)5211. 矢状断で diencephalic leaf の下後方に脳底動 脈頂部は位置し, 後有孔質 (posterior perforated substance）に穿通する各種動脈（posterior thalamo-perforating branch, paramedian thalamic artery, superior and inferior paramedian mesencephalic artery）が分岐する（Fig. 3)。脳底動脈を含めこれら穿通動脈の損傷は厳に注意し なければならない13)1418)。 また両外側では後交通動脈か ら分岐する pre-mammillary artery を認め, 同血管の走行 がETV の径を制限する因子の一つになる。

一方 mesencephalic leaf は通常脳底動脈前壁に付着し て，そのまま cerebello-pontine membrane に連続す $3^{2221)}$. 外側で側頭葉内側壁に付着し，小脳テントの自 


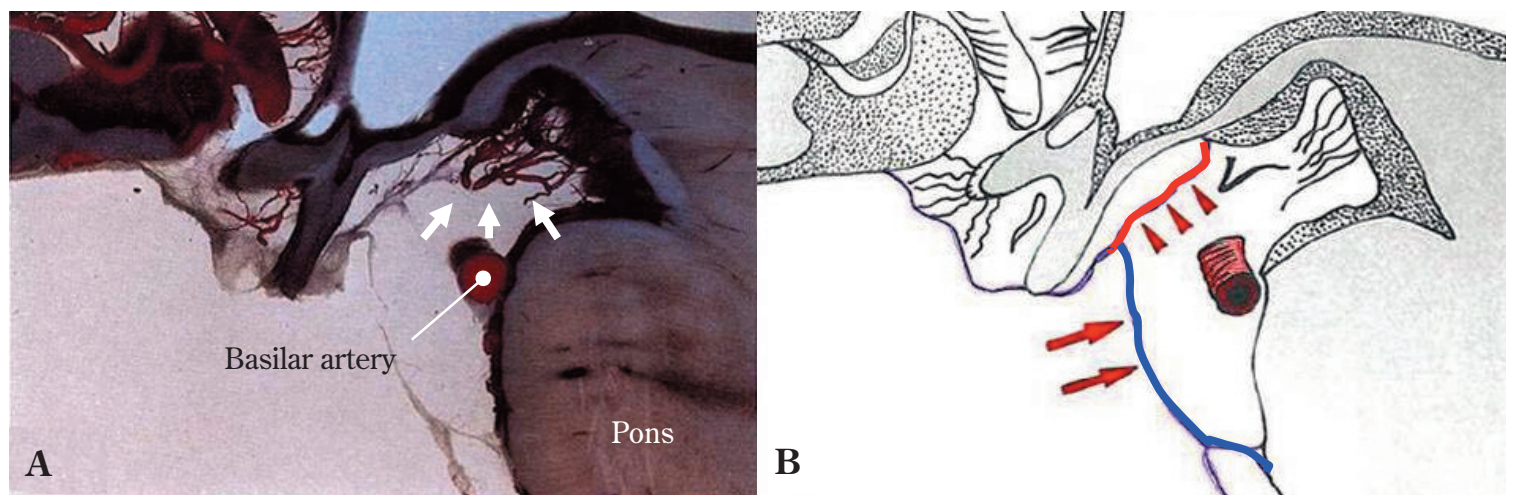

Fig. 3 Sagittal section pattern of the interpeduncular cistern

A : Perforating arteries toward the midbrain from the top of the basilar artery and posterior cerebral artery (arrow) were revealed under the diencephalic leaf of Liliequist's membrane.

B : An illustration of the diencephalic leaf (arrow head) and the mesencephalic leaf (arrow) of Liliequist's membrane. (modified from ref. 8)

由縁との間には隙間がある。脆弱で網状を呈する膜のこ とが多いが，まれに強く肥厚していたり，多層構造を呈 するような症例（Fig. 4）もある1)。このような症例では mesencephalic leaf も穿破し, prepontine cistern まで髄液 路を確保することで ETV が奏効することがある ${ }^{3) 6}$ の で, 術前 MRI における CISS 画像の取得と解剖構造の詳 細な観察が肝要である。

\section{3 脊䯣髄膜瘤に伴う水頭症}

脊髄髄膜瘤患者の多くは先天性水頭症を合併し，ETV の適応になることがある。この水頭症はキアリ奇形をは じめとする “pan-CNS anomaly” の結果9)であり, 脳室系 にもさまざまな構造異常を伴う。側脳室前角からアプ ローチすると，狭小化してスリット状になったモンロー 孔を認めることが多い（Fig. 5A）。脈絡叢の陰に隠れて 同定困難なこともある。しかしモンロー孔は閉塞してお らず，径 $3.0 \mathrm{~mm}$ 弱の神経内視鏡の通過は容易に可能で ある。第三脳室を観察すると，その横径は狭小化し大き な視床間橋（massa intermedia）を合併する。第三脳室底 部は菲薄化に乏しいことも多く，灰白隆起部に第三脳室 底を横断するような譬状隆起を認める（Fig. 5B）。脚間 槽には幾重にも重なった厚い膜様構造を認めることが多 い. ETVでは譬状隆起の直上を穿孔して, 脚間槽の膜様 構造を完全に穿破することで“to and fro movement”が得 られる ${ }^{11) 12)}$.

中脳水道を観察してみると，入口部はスリット状を呈 しており, 神経内視鏡先端部から洗浄用のリンゲル液を 流出して水圧をかけることで，この入口部が徐々に開口 していくことが確認できる，われわれの経験では 1 例の
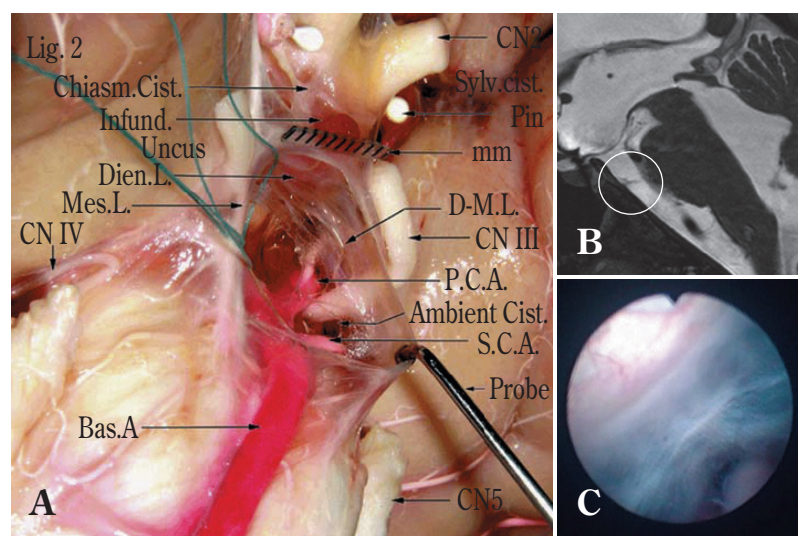

Fig. 4 Liliequist's membrane and cisterns

A : A cadaveric inter-peduncular cistern. Dien. L. : diencephalic leaf of Liliequist's membrane, Mes. L.: mesencephalic leaf of Liliequist's membrane, diencephalic- mesencephalic leaf, Bas. A: basilar artery, P. C.A.: posterior cerebral artery, S.C.A.: Superior cerebellar artery, Chiasm. Cist.: chiasmatic cistern, Sylv. cist.: sylvian cistern, Ambient Cist. : ambient cistern, Infund.: infundibulum, CN2: optic nerve, CNIII : oculomotor nerve, CNIV: trochlear nerve, CN5: trigeminal nerve (modified from ref. 21)

B : Sagittal CISS MR-image demonstrating the membranous structure before the pons (circle).

C: An endoscopic image of the thickened mesencephalic leaf of Liliequist's membrane.

み Russel の分類したいわゆる forking に相当する例が疑 われたが，中脳水道の完全閉塞例は認めていない。 


\section{Aqueductoplasty}

\section{1 中脳水道の外観}

中脳水道は正常成人では約 $15 \mathrm{~mm}$ 長，幅は $0.5 \sim 2.84$ $\mathrm{mm}$ と報告されている。 入口部は正常では背側を底辺と する類三角形を呈するが，水頭症例では卵円形に拡大す る。壁に一定のコンプライアンスを有し，心拍動に同期 して伸縮する。病的条件下では $6 \mathrm{~mm}$ 以上にまで拡張す

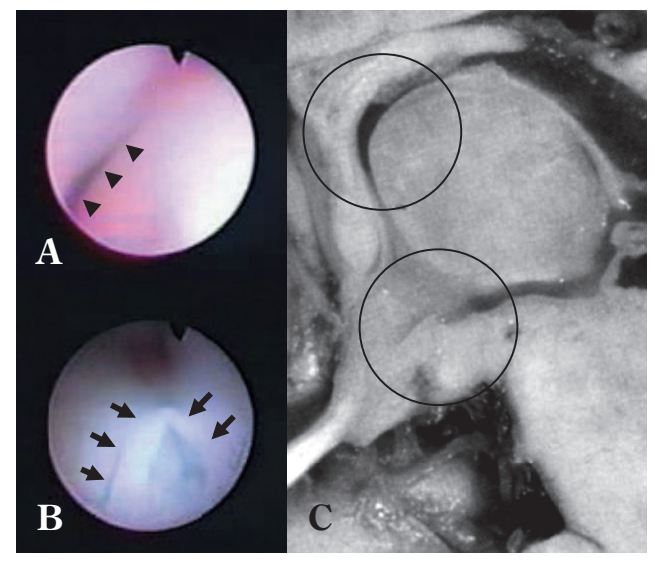

Fig. 5 Anatomical variations in a case with myelomeningocele

A : Slit shaped foramina of Monro.

B : Transverse fold on the narrow floor of the third ventricle.

$\mathrm{C}:$ A cadaveric cross section of the third ventricle in a case with myelomeningocele. (modified from the ref. 9)
るとされ，外径 4.5〜 $5.0 \mathrm{~mm}$ の脳室鏡が通過する機械的 な圧迫に,一定のコンプライアンスを持って耐えられる。 Longatti $ら^{7)}$ は，内視鏡所見を基に中脳水道を adytum, first constriction, ampulla, second constriction, posterior part の 5 分節に分類した（Fig. 6).ここで 2 力所の狭窄 部（constriction）にあたる部位は上丘，下丘に相当し， この間に位置する crucial tegmental sulcus が膨大部 (ampulla)にあたるとしている.

\section{2 手技と神経路}

術前 MRI の矢状断像で中脳水道の傾きを考慮しつつ, モンロー孔と中脳水道入口部を結ぶ線上に穿頭し，脳弓 と静脈角および中脳被蓋の損傷を防ぐ. 通常成人例では, 冠状縫合の前方 3〜 $5 \mathrm{~cm}$ ，中心線より $1 \sim 1.5 \mathrm{~cm}$ の部が 目安である。中脳水道入口部まで脳室鏡を進め, Fogarty balloon catheter を中脳水道内に挿入してバルーンを拡 張させるのが一般的な手技である ${ }^{416) 19)}$ (Fig. 7)。ここで 硬性鏡使用時は，中脳水道の強い傾斜のためカテーテル が四丘板（quadrigeminal plate）を貫く危険性があること に留意する20)

EAP の適応となる膜様閉塞は前述の狭窄部に多い. 特 に second constriction での膜様閉塞はしばしば遭遇する 病態で, この際 adytum から ampulla は漏斗型に拡張す $3^{16)}$. Second constriction のレベルで中脳被蓋側では, 滑車神経路が上衣組織に近接しており，中脳水道壁への 過度の圧迫や熱凝固処置具による損傷を避けるよう注意 が必要である。一方 first constriction レベルの被蓋側に は，動眼神経核および内側緹束（medial longitudinal fas-

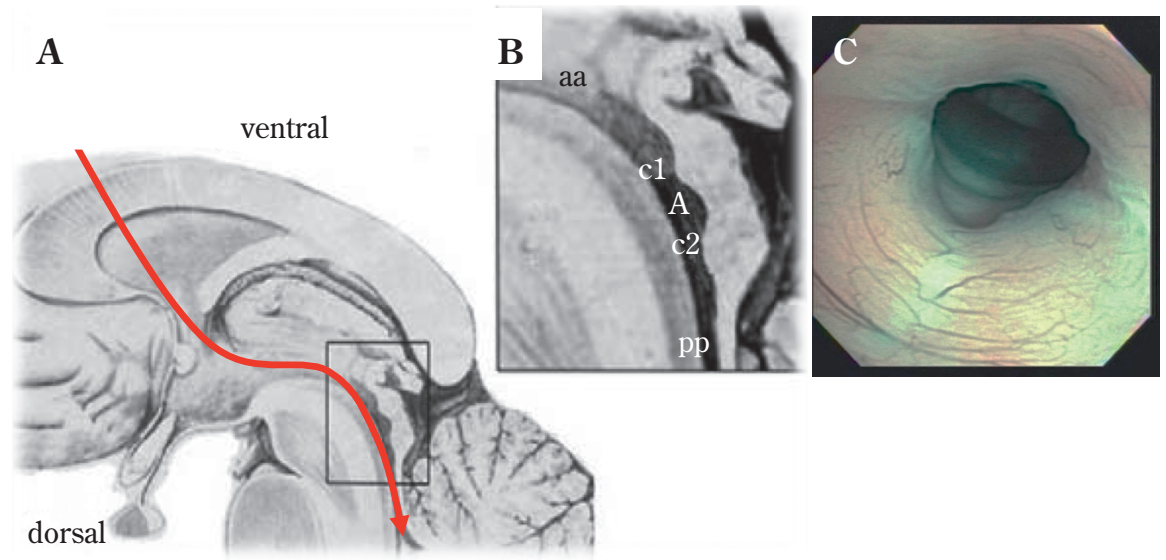

Fig. 6 Anatomy of the aqueduct

A : The redline shows the direction of the endoscope and forceps in EAP.

B : Segments of the aqueduct, aa : aditus aqueducti, $\mathrm{c} 1$ : first constriction, A : ampulla, c2: second constriction, pp : posterior part. (modified from ref. 7)

$\mathrm{C}:$ Endoscopic view from the orifice into the aqueduct. 
ciculus）が位置しており ${ }^{10)}$ ，これら神経路，神経核の損 傷を避けなければならない（Fig. 8).

また，孤立性第四脳室に伴う中脳水道の閉塞も，EAP のよい適応病態と考えられている。ただし報告例の多く は, 単純な EAP では術後閉塞率が高いため, 中脳水道 内にステントを留置することを推奨している.

\section{Temporal ventriculostomy}

Temporal ventriculostomy は, 側脳室三角部 (trigonum) 付近の占拠性病変や広汎な癒着性病変によって, 側脳室 下角（inferior horn）が孤立して拡大するような水頭症病 態で適応となる ${ }^{19)}$ 。病変側の耳介直上に骨葖を設置し, できる限り低い位置から下角にシースおよび内視鏡を挿 入する。まず脈絡叢を確認して，ランドマークとすべき 脈絡裂（choroidal fissure）を同定する，拡大の程度次第 で脳室壁は菲薄化していることもあるが, 通常脳槽側の 構造は確認できない。ここで前脈絡叢動脈の損傷を避け ることが重要である，通常, 脈絡裂を前方に伸ばした直 線を想定して，それょりやや外側の脈絡点（choroidal point）ょり前方で脳槽へ向けて穿孔する（Fig. 9）。穿孔 部の先を carotid cistern から後方の crural cistern に向か うようにして, 前脈絡叢動脈や他の穿通枝の損傷を回避 する。この際，動眼神経の損傷にも注意を払うべきであ る ${ }^{19)}$ 。この部では髄液のいわゆる pulsatile flow がそし く, また十分な径の開空が得られない. そのためステン トの設置による術後閉塞への対策が必要とされることも ある。

\section{Quadrigeminal cistern arachnoid cyst}

四丘体槽くも膜囊胞では，脳室-脳槽開空と同時に囊 胞壁を穿破することが求められる。同病変は上方進展型 と前方進展型に大別され，各型によって有利なアプロー チが異なる，前方進展型では，第三脳室後方での突出部 に開空して囊胞壁を穿破するのが容易である。松果体陥 凹部で菲薄化していることも多く，開空の指標となる. 一方, 上方進展型では第三脳室後半部側からの開空での 指標に乏しく，むしろ側脳室体部から内側後方に向かっ て四丘体槽に穿孔するほうが有利である（Fig. 10）。この 際, 術前 MRI の冠状断像で内大脳静脈 (internal cerebral vein）と脈絡叢の位置を確認しておくことが肝要である. 脈絡叢の内側で後方に向けて穿孔して内視鏡を挿入する と, 内後頭静脈（internal occipital vein）を穿孔部に近接 して確認することがあり，四丘体槽内での内視鏡操作の 際に損傷しないような注意が必要である（Fig. 11）。これ ら深部静脈の保全のため, 側脳室からの穿孔には鈍的操 作が推奨される。十分な四丘体槽への開空と囊胞壁の切

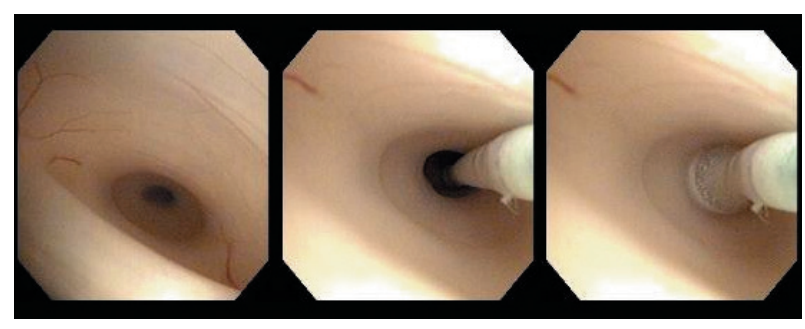

Fig. 7 Aqueductoplasty for membranous obstruction at the segment of the second constriction

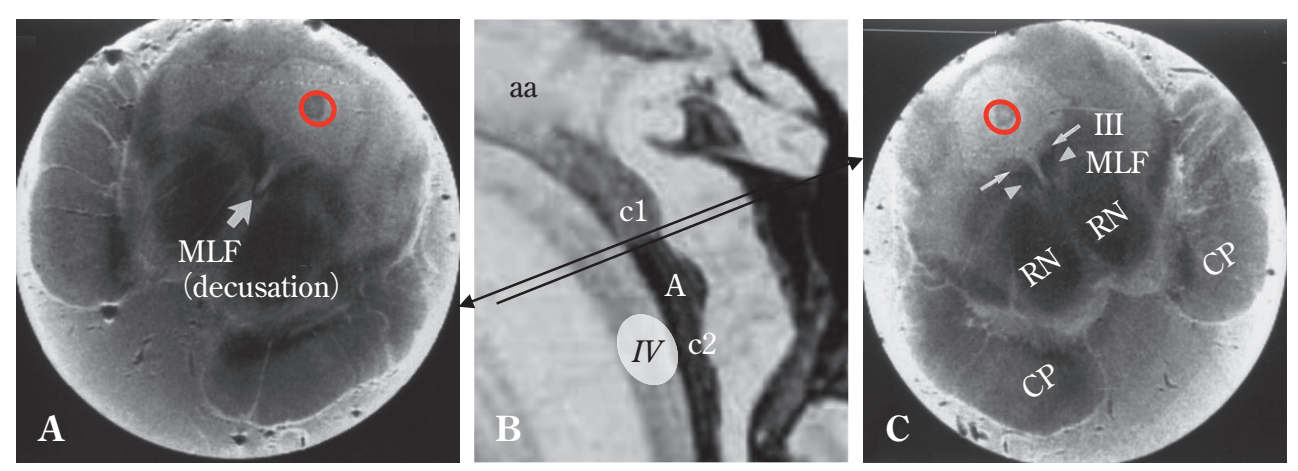

Fig. 8 Peri-aqueductal neural fibers and nucleus

A, C : Level of the first constriction. The medial longitudinal fasciculus and oculomotor nucleus are shown close to the aqueduct. (modified from ref. 10)

B : The trochlear nerve is located close to the aqueduct at the second constriction. (MLF : medial longitudinal fasciculus, III : oculomotor nucleus, IV : trochlear nerve, $\mathrm{RN}:$ red nucleus, $\mathrm{CP}:$ cerebral peduncle) 
離が達成されれば，中脳水道が開口して脳室内䯣液路の 閉塞が解除される。閉塞解除が不完全と思われる例では ETV が追加されることもある.

なお本囊胞と類似する病態として mesencephalic
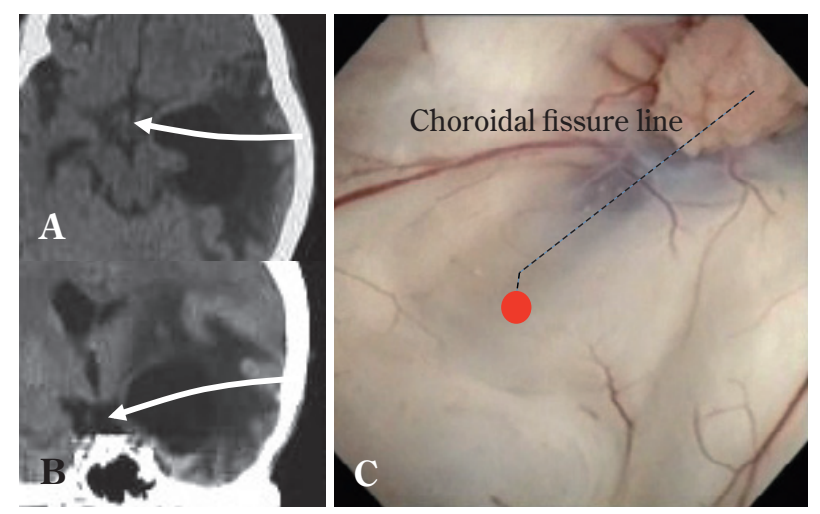

Fig. 9 Temporal ventriculostomy in a case with a trapped left inferior horn

A, B : Approach route in left temporal ventriculostomy. (A: axial section, B : coronal section)

C : Endoscopic view of the left inferior horn. The red circle, in front of the choroidal point and outside of the choroidal fissure should be perforated. ependymal cyst がある。これは中脳の脳室上衣下におけ る囊胞性病変であり, 第三脳室側からの直接穿孔の適応 である，術前 MRI の際，CISS 画像の矢状断面で四丘体 槽の位置を確認することが，鑑別に有用である ${ }^{15)}$ (Fig. 12).

\section{おわりに}

水頭症および関連する囊胞性疾患に対して，髄液循環 路を作成する代表的な脳室鏡手術を提示し，必要な解剖 と知識を概説した。水頭症関連疾患では正常構造を留め ていない症例があり，術前画像の詳細な検討は必須であ る. 加えて, 術中のランドマークとなる解剖構造を把握 することが肝要である。これは立体視に難がある内視鏡 手術に求められる“visual cue” の獲得にも関連すること を付言しておきたい.

本稿の内容は第 32 回日本脳神経外科コングレス総会 （2012 年 5 月，横浜）で発表したものです。

本稿に関して申告すべき利益相反はありません。

本文中，一部の日本語訳は関連用語集に見当たらず，直訳 したものです.
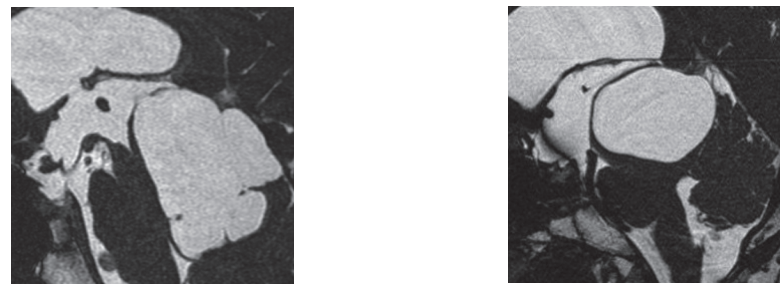

Location

Approach

Operative procedure

Fig. 10 Schema for treatment of cysts in the quadrigeminal cistern and midbrain (modified from ref. 15) 

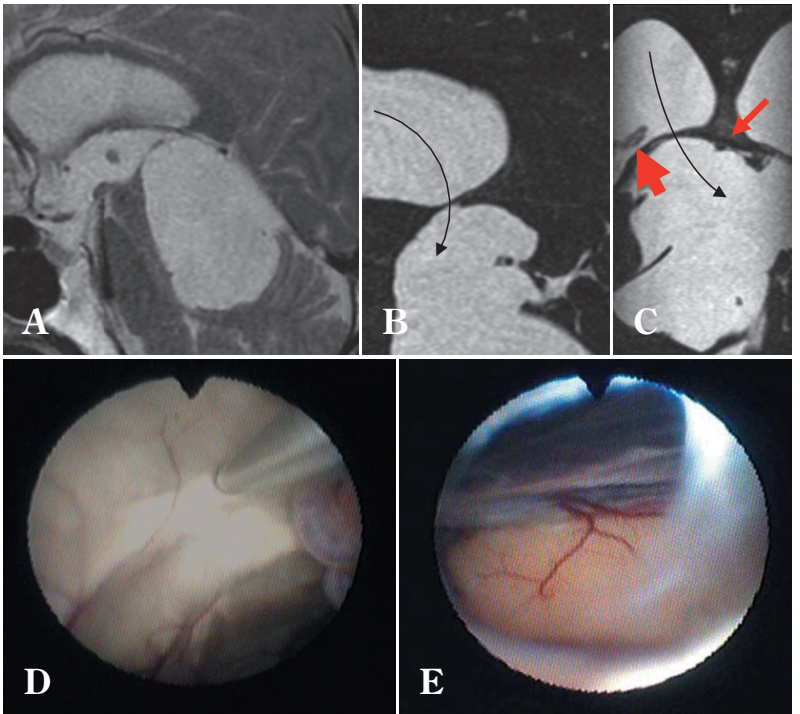

Fig. 11 Endoscopic cyst-ventriculostomy in a case with an arachnoid cyst in the quadrigeminal cistern

A : T2-weighted MR-image demonstrating a cyst in the quadrigeminal cistern with upper growth.

B : Sagittal CISS MR-image showing the direction of the endoscope.

C : Coronal CISS MR-image showing the direction of the endoscope. The choroid plexus in the right lateral ventricle (large arrow) and internal cerebral vein (small arrow) are demonstrated.

D : Fenestration with forceps into the quadrigeminal cistern.

$\mathbf{E}$ : The internal occipital artery was revealed in the quadrigeminal cistern.

\section{文 献}

1) Anik I, Etus V, Anik Y, Ceylan S: Role of interpeduncular and prepontine cistern cerebrospinal fluid flow measurements in prediction of endoscopic third ventriculostomy success in pediatric triventricular hydrocephalus. Pediatr Neurosurg 46:344-350, 2010.

2) Anik I, Ceylan S, Koc K, Tugasaygi M, Sirin G, Gazioglu N, Sam B: Microsurgical and endoscopic anatomy of Liliequist's membrane and the prepontine membranes: cadaveric study and clinical implications. Acta Neurochir 153: 1701-1711, 2011.

3) Dinçer A, Kohan S, Ozek MM: Is all "communicating" hydrocephalus really communicating? Prospective study on the value of $3 \mathrm{D}^{-}$-constructive interference in steady state sequence at 3 T. AJNR Am J Neuroradiol 30: 1898-1906, 2009.

4) Fritsch MJ, Kienke S, Manwaring KH, Mehdorn HM : Endoscopic aqueductoplasty and interventriculostomy for the treatment of isolated fourth ventricle in children. Neurosurgery $\mathbf{5 5}: 372-379,2004$.

5) Froelich SC, Abdel Aziz KM, Cohen PD, van Loveren HR, Keller JT: Microsurgical and endoscopic anatomy of Liliequist's membrane: a complex and variable structure of the basal cisterns. Neurosurgery 63 (Suppl 1) : ONS1-

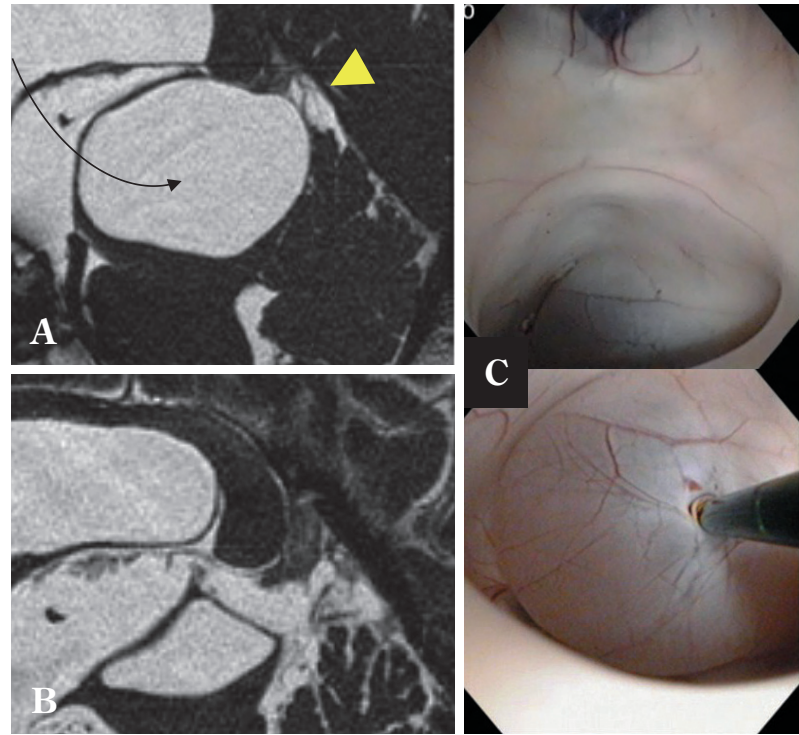

Fig. 12 Mesencephalic ependymal cyst

A, B : Sagittal CISS MR-image before (A) and after (B) operation demonstrate the quadrigeminal cistern beside the cyst.

$\mathrm{C}:$ Endoscopic view of the mesencephalic ependymal cyst from the third ventricle.

8; discussion ONS8-9, 2008.

6) Fushimi $Y$, Miki $Y$, Ueba T, Kanagaki M, Takahashi T, Yamamoto A, Haque TL, Konishi J, Takahashi JA, Hashimoto N, Konishi J: Liliequist membrane: three-dimensional constructive interference in steady state $\mathrm{MR}$ imaging. Radiology 229: 360-365, 2003.

7) Longatti P, Fiorindi A, Perin A, Martinuzzi A: Endoscopic anatomy of the cerebral aqueduct. Neurosurgery $\mathbf{6 1}$ (Suppl) : 1-6, 2007.

8) Lü J, Zhu X: Microsurgical anatomy of the interpeduncular cistern and related arachnoid membranes. J Neurosurg 103:337-341, 2005.

9) McLone DG, Naidich TP: Developmental morphology of the subarachnoid space, brain vasculature, and contiguous structures, and the cause of the Chiari II malformation. AJNR Am J Neuroradiol 13: 463-482, 1992.

10) Miller MJ, Mark LP, Ho KC, Haughton VM: Anatomic relationship of the oculomotor nuclear complex and medial longitudinal fasciculus in the midbrain. AJNR Am J Neuroradiol 18: 111-113, 1997.

11) Mori H, Oi S, Nonaka Y, Tamogami R, Muroi A: Ventricular anatomy of hydrocephalus associated with myeloschisis and endoscopic third ventriculostomy. Childs Nerv Syst 4: 717-722, 2008.

12）西山健一, 森 宏, 吉村淳一, 田中隆一: 先天性水頭症 における䯣液路の発達一神経内視鏡所見。脳 $21 \quad 8: 42-$ 48, 2005.

13）西山健一, 森 宏, 吉村淳一, 藤井幸彦：Endosocpic third ventriculostomy の合併症とその回避法・対処法一自験 100 例の検討から一. 脳外誌 7:524-532，2007.

14) Nishiyama K, Mori H, Yoshimura J, Fujii $Y$ : Endoscopic fenestration of the third ventricle in the reverse direction. Childs Nerv Syst 24:507-508, 2008. 
15）西山健一，吉村淳一，岡本浩一郎，松澤 等，藤井幸彦： 手術に役立つ局所画像診断 Mesencephalic ependymal cyst に対する脳室鏡視下手術. 脳外速報 20：538-543， 2010.

16）西山健一, 藤井幸彦：神経内視鏡下中脳水道形成術。脳 外速報 22：910-916，2012.

17) Oka K, Yamamoto $M$, Ikeda K, Tomonaga $M$ : Flexible endoneurosurgical therapy for aqueductal stenosis. Neurosurgery $33: 236-243,1993$.

18) Schroeder HW, Niendorf WR, Gaab MR: Complications of third ventriculostomy. J Neurosurg $\quad \mathbf{9 6}:$ 1032-1040, 2002.
19) Schroeder HWS, Oertel J, Gaab MR: Endoscopic treatment of cerebrospinal fluid pathway obstructions. Neurosurgery 60 (ONS Suppl 1) ONS-44-52, 2007.

20) Schulz M, Goelz L, Spors B, Haberl H, Thomale UW : Endoscopic treatment of isolated fourth ventricle: clinical and radiological outcome. Neurosurgery 70:847-859, 2012.

21) Sufianov AA, Sufianova GZ, Iakimov IA: Microsurgical study of the interpeduncular cistern and its communication with adjoining cisterns. Childs Nerv Syst 25:301308, 2009 .

\section{水頭症の内視鏡手術に必要な解剖と知識}

\section{西山 健一 藤井 幸彦}

本稿では, 水頭症および関連する囊胞性疾患に対して剈焲路を作成する脳室鏡手術を提示し，必要 な解剖と知識を概説した．ここで術式は “脳室-脳槽短絡術” と“脳室内閉塞機転の解除”に大別さ れる. 鏡視下で目印となる脳室内構造の把握に加えて, 前者では脳槽の構築と内部血管の, 後者では 脳室壁直下の神経路と神経核の理解が必須である。“Third ventriculostomy”では，両側乳頭体と漏斗 陥凹とを結ぶ三角形の中心を目印に,脳底動脈および同頂部から中脳に向かう動脈群の損傷を避けて， 脚間槽に穿孔する.この際, 脚間槽を緑取る二葉の Liliequist’s membrane の確認が重要である. “Temporal ventriculostomy”では脈絡裂の仮想延長線を目印に，前脈絡動脈の損傷を避けるように carotid cistern の後方から crural cistern に穿孔する. “Aqueductoplasty” では, 動眼神経核, 内側縦束, 滑 車神経路の損傷を避ける，なお，水頭症関連疾患では正常構造を留めていない症例があり，術前画像 の詳細な検討が肝要である. 